\title{
LIGHT INFANTRY VULNERABILITIES THAT REPRESENT STRATEGIC VULNERABILITY IN OPERATIONS OTHER THAN WAR
}

\author{
A Monograph \\ by
}
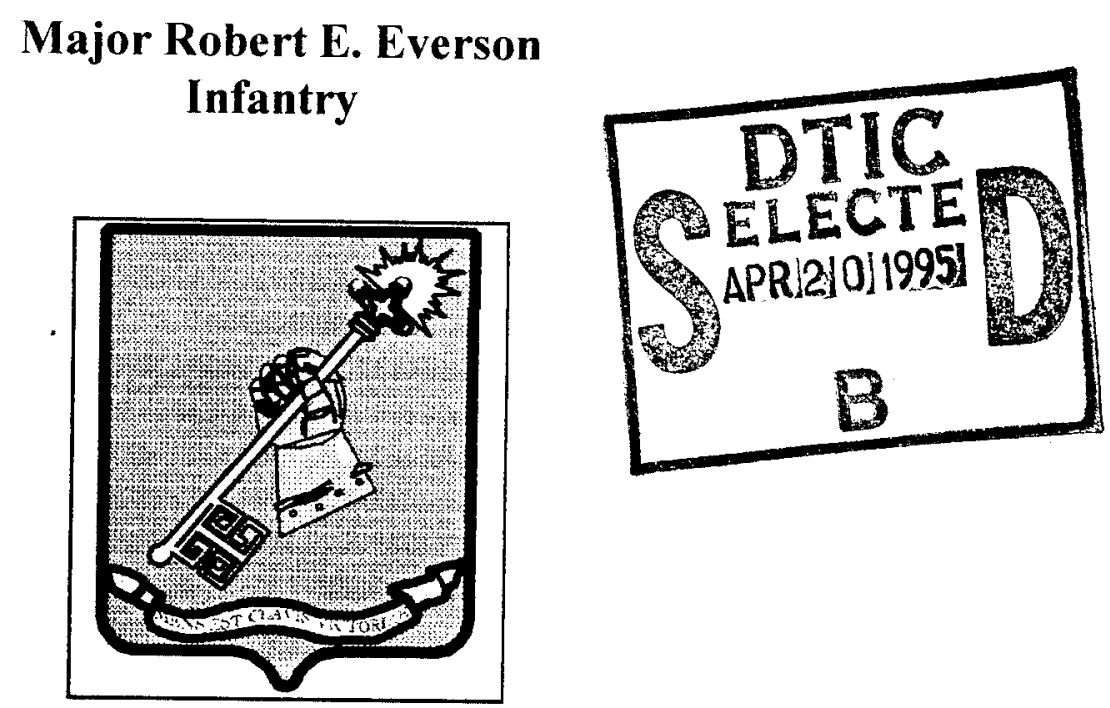

School of Advanced Military Studies

United States Army Command and General Staff College

Fort Leavenworth, Kansas

First Term AY 94-95

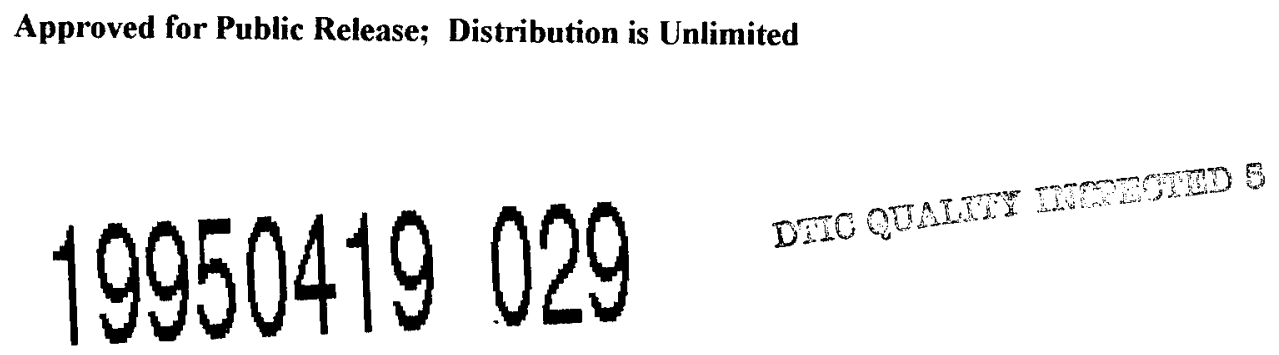




\section{REPORT DOCUMENTATION PAGE}

Public reoorting burden for this collection of information is estimated to average 1 hour per response, including the time for reviewing instructions, searching existing data sources, gathering and maintaining the data needed, and completing and reviewing the collection of information. Send comments regarding this burden estimate or any other aspect of this collection of information, including suggestions for reducing this busden. 10 Washington Headcuarters services, Directorate for Information Operations and Reports, 1215 lefferson Davis Highway, Sulte 1204. Arlington, VA 22202-4302, and to the Office of Management and Budget, Paperwork Reduction Project (0704-0 188), Washington. DC 20503.
1. AGENCY USE ONLY (Leave blank)
2. REPORT DATE
3. REPORT TYPE AND DATES COVERED MONOG RAPH

\section{TITLE AND SUBTITLE}

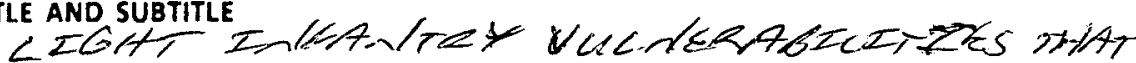
5. FUNDING NUMBERS

REPAESENT STRATECTC VUUNERAGTLIXY IN

OWEATFONS OTHER THAS WAR

6. AUTHOR(S)

$$
\text { MAT ROBERTE. EVERSON, USA }
$$

\section{PERFORMING ORGANIZATION NAME(S) AND ADDRESS(ES)}

SCHOOL OF AOVANCED MILITTARY STUOAES

8. PERFORMING ORGANIZATION ArTor: ATzL - SLaV

TORT LEAVENWORTH, KANSAS 66027-600 $\operatorname{com}(913) 684+3310$ Autollon' $552-3437$

9. SPONSORING / MONITORING AGENCY NAME(S) AND ADDRESS(ES) REPORT NUMBER

11. SUPPLEMENTARY NOTES

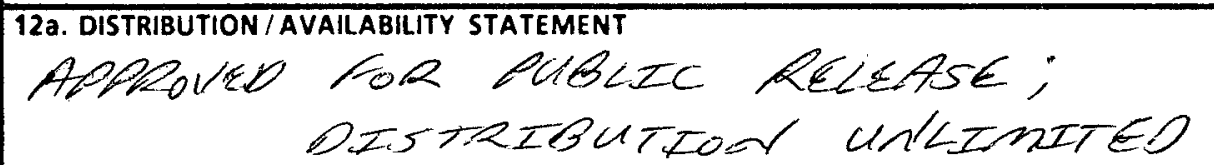

13. ABSTRACT (Maximum 200 words)

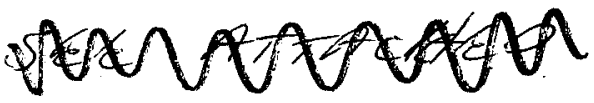

\begin{tabular}{|c|c|c|c|}
\hline $\begin{array}{l}\text { 14. SUBJECT TERMS } \\
\text { OOT CL } \\
\text { LICATT INA } \\
\text { URBAT WNA }\end{array}$ & $\begin{array}{l}\text { Inth } \\
\text { PuE } \\
\text { STPATE }\end{array}$ & $\begin{array}{l}\text { WTEY HACTICS } \\
\text { SIC ODEVION } \\
\text { SIC VULNERABILIT }\end{array}$ & \begin{tabular}{|l} 
15. NUMBER OF PAGES \\
$5 \%$ \\
16. PRICE CODE
\end{tabular} \\
\hline $\begin{array}{l}\text { 17. SECURITY CLASSIFICATION } \\
\text { OF REPORT } \\
\text { UNCLASSE }\end{array}$ & $\begin{array}{l}\text { 18. SECURITY CLASSIFICATION } \\
\text { OF THIS PAGE } \\
\text { UNCLASSEF FEO }\end{array}$ & $\begin{array}{l}\text { 19. SECURITY CLASSIFICATION } \\
\text { OF ABSTRACT } \\
\text { UNCLASSEAFEO }\end{array}$ & $\begin{array}{l}\text { 20. LIMITATION OF ABSTRAC } \\
\text { uN/LDANETED }\end{array}$ \\
\hline
\end{tabular}


The Report Documentation Page (RDP) is used in announcing and cataloging reports. It is important that this information be consistent with the rest of the report, particularly the cover and title page. Instructions for filling in each block of the form follow. It is important to stay within the lines to meet optical scanning requirements.

Block 1. Agency Use Only (Leave blank).

Block 2. Report Date. Full publication date including day, month, and year, if available (e.g. 1 Jan 88). Must cite at least the year.

Block 3. Type of Report and Dates Covered. State whether report is interim, final, etc. If applicable, enter inclusive report dates (e.g. 10 Jun 87 - 30 Jun 88 ).

Block 4. Title and Subtitle. A title is taken from the part of the report that provides the most meaningful and complete information. When a report is prepared in more than one volume. repeat the primary title, add volume number, and include subtitle for the specific volume. On classified documents enter the title classification

Block 5. Funding Numbers. To include contract and grant numbers; may include program element number(s), project number(s), task number(s), and work unit number(s). Use the following labels: in parentheses.

$$
\begin{aligned}
& \text { C - Contract } \\
& \text { G - Grant } \\
& \text { PE - Program } \\
& \text { Element }
\end{aligned}
$$

Block 12a. Distribution/Availability Statement. Denotes public availability or limitations. Cite any availability to the public. Enter additional limitations or special markings in all capitals (e.g. NOFORN, REL, ITAR).

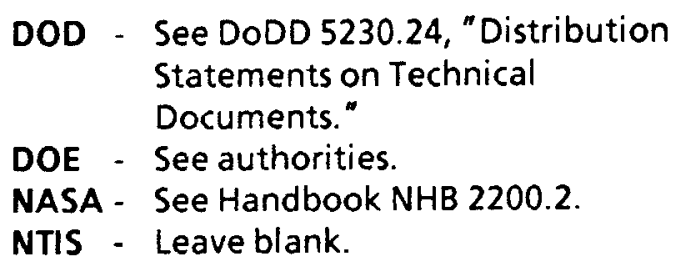

Block 12b. Distribution Code.

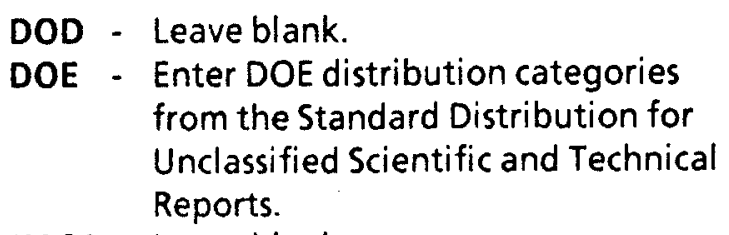

Block 13. Abstract. Include a brief (Maximum 200 words) factual summary of the most significant information contained in the report.

Block 14. Subject Terms. Keywords or phrases identifying major subjects in the report.

responsible for writing the report, performing the research, or credited with the content of the report. If editor or compiler, this should follow the name(s).

Block 7. Performing Organization Name(s) and Address(es). Self-explanatory.

Block 8. Performing Orqanization Report Number. Enter the unique alphanumeric report number(s) assigned by the organization performing the report.

Block 9. Sponsoring/Monitoring Agency Name(s) and Address(es). Self-explanatory.

Block 10. Sponsoring/Monitoring Agency Report Number. (If known)

Block 11. Supplementary Notes. Enter information not included el sewhere such as: Prepared in cooperation with...; Trans. of...; To be published in.... When a report is revised, include a statement whether the new report supersedes or supplements the older report.
Block 15. Number of Pages. Enter the total number of pages.

Block 16. Price Code. Enter appropriate price code (NTIS only).

Blocks 17.-19. Security Classifications. Selfexplanatory. Enter U.S. Security Classification in accordance with U.S. Security Regulations (i.e., UNCLASSIFIED). If form contains classified information, stamp classification on the top and bottom of the page.

Block 20. Limitation of Abstract. This block must be completed to assign a limitation to the abstract. Enter either UL (unlimited) or SAR (same as report). An entry in this block is necessary if the abstract is to be limited. If blank, the abstract is assumed to be unlimited. 


\section{SCHOOL OF ADVANCED MILITARY STUDIES \\ MONOGRAPH APPROVAL}

Major Robert E. Everson

Title of Monograph: Light Infantry Vulnerabilities that Represent Strategic Vulnerability in operations other Than War

Approved by:

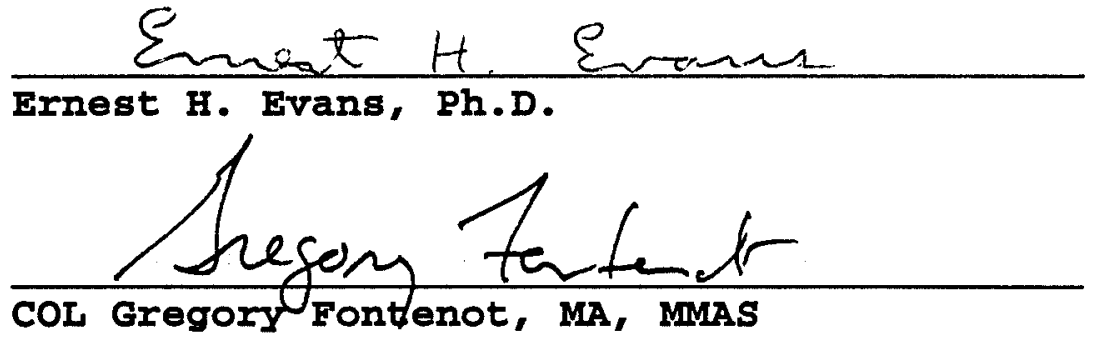

Philip S. Brorhm
Monograph Director Director, school of Advanced Military Studies

Director, Graduate Degree Program 


\begin{abstract}
LIGHT INFANTRY VULNERABILITIES THAT REPRESENT STRATEGIC VULNERABILITY IN OPERATIONS OTHER THAN WAR bY MAJ RObert E. Everson, USA, 49 pages.
\end{abstract}

In Operations other Than War (OOTW) U.S. forces will be involved in armed conflict in what are called, ironically, "peace operations". The three peace missions, peacekeeping, peace enforcement, and peacemaking, are not a continuum in peace operations and hence the U.S. could find itself entering a situation where one type of peace operation can change quickly and unexpectedly to another type of peace mission. The U.S. has found itself entering into peace operations with questionable public support; the operation then takes a dramatic turn after percieved failure.

The operations in Beirut and Somalia are both examples where light infantry vulnerabilities were used by hostile forces to change the course of strategy for the U.S. Each example occured in urban areas, the hardest of all combat environments. In both cases the U.S. forces suffered large casualties; these casualties caused the American public to perceive the operations as failures and subsequently to demand that the NCA give the order to withdraw.

The Gallup poll displays the ambivalence of the U.S. public prior to Beirut, Somalia and Haiti, then further shows the change from apathy to opposition in the OOTW after the incidents in Beirut and Somalia. Within the U.S. military the debate over the utility and practicality of the Light infantry division has not changed since the cold war period; however, a small part of the argument has changed. Although light infantry was designed to fight unaugmented in an urban area in a general war situation, the light infantry is unsuited to fight unaugmented in an urban area in an OOTW.

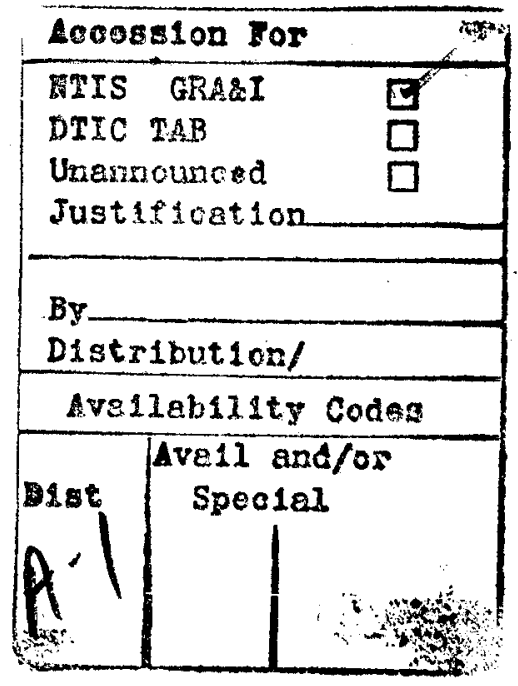


Page

APPROVAL PAGE . . . . . . . . . . . . . . . .

ABSTRACT. . . . . . . . . . . . . . . . ii

ONE. INTRODUCTION. . . . . . . . . . . . . . 1

TWO. THE STRATEGIC ENVIRONMENT FOR OOTW. . . . . 5

THREE. THE OOTW CONFLICT . . . . . . . . . . . . 17

FOUR. THE NATIONAL WILL . . . . . . . . . 38

FIVE. CONCLUSION. . . . . . . . . . . 43

ENDNOTES. . . . . . . . . . . . . . . . 50

BIBLIOGRAPHY. . . . . . . . . . . . . . 55 


\section{INTRODUCTION}

The elimination of the Soviet Union as a superpower has caused the international situation to change from a bipolar struggle between western democracy and communism to a world where only one country is considered a superpower by the world community. The United states is the only country which maintains a capability and a policy of projecting significant forces outside of its' own borders. The U.S. is now viewed as the major player in the international arena. The most recent National Security strategy states that the U.S. will continue to involve itself in international problems to support democracy and conflict resolution; and by this statement the U.S. has accepted the fact she is and will remain a significant member of the world community. 1 The threat to global stability has changed and so has the strategic focus of the U.S. The U.S. has shifted from a global strategy with an emphasis on maintaining stability in the population and industrial regions of Europe, southwest Asia, and northeast Asia to a global strategy which is predominantly concerned with stability in southwest and northeast asia. The lack of a global and strategic military threat by any potential adversary in these two regions confines any possible conflict to within that region. Third world regions once areas of potential conflict between superpowers, such as Central America and Africa, currently occupy a much less important role in American national security concerns than they did during the cold war. 
The shift in the political structure of eastern Europe has created numerous internal changes in the intruments of power for the U.S.; specifically in the organization and composition of the U.S. military. The military threat to the U.S. was dramatically reduced and consequently much of the force structure of the four services of the U.S. military was also reduced. This reduction was conducted proportionately and the U.S. now maintains the same capabilities that it had during the cold war, but on a smaller scale.

The U.S. military, including the U.S. Army, must confront again in a new form a mission with which it has long been familiar; namely, a spectrum of operations called Operations Other Than War (OOTW). The OOTW spectrum involves all manner of operations that the military could find itself participating in short of general war. Examples are disaster relief after Hurricane Andrew in Florida in 1993, assisting in riot control as in Los Angeles in 1992, fighting drug trafficking from 1992 to the present and providing aid to displaced Kurdish refugees in Turkey after operation Desert Storm.

This spectrum of operations also includes small scale peacekeeping, peace enforcement or peacemaking operations. Peacekeeping and peace enforcement operations are where the military is used to support a peaceful state after a recent conflict. The emphasis is primarily diplomatic in both cases, but peace enforcement involves a more active military 
posture than peackeeping. Peacemaking is an operation to establish peace in an ongoing conflict. The emphasis is initially military with a subsequent switch to diplomatic measures. Peacekeeping, peace enforcement, and peacemaking operations are currently operations which could possibly involve combat operations against an irregular force or a small army. There are other OOTW situations which may involve U.S. forces in combat, such as Noncombatant evacuation operations(NEO) or antiterrorism operations, but all of the three peace support missions will invariably place U.S. Army forces into a potential combat environment. The U.S. military currently places a heavy reliance on its' light forces to conduct the OOTw tasks. Light forces were traditionally viewed as forces which augmented the heavy armor and mechanized forces during the cold war period. The shift from forward basing to power projection has placed a greater premium on strategic lift assets during a time when strategic lift resources are dwindling. The regional focus of the U.S. strategic outlook has caused OOTW to become the preferred method of dealing with international crises; specifically, an early response to a potential crisis could prevent a larger and more complicated crisis from developing. The increase in regional instability, the emphasis on power projection instead of forward basing, and the potential for ОOTW operations to result in combat in remote regions have all combined to cause the U.S. to rely on her less sophisticated combat forces to defend its 
national security interests in the post-cold war world. This study will attempt to discern whether or not the U.S. military's light forces, particularly the Army's light infantry divisions, are capable of functioning in the tactical OOTW environment in support of the strategic objectives of the U.S. This study does not question whether or not light infantry should remain in the Army's force structure, but is instead concerned with the structure of the light infantry in a particular situation. The specific OOTW missions are peacemaking and peacekeeping where there is an ongoing conflict or a potential conflict. The primary question of this study is, "Does the Light Infantry in Operations Other Than War provide United States adversaries a strategic vulnerability?

The secondary questions of this study are to review the effects on the National Command Authority(NCA) and on the public of both success or perceived success in an OOTW conflict and of failure or perceived failure in such conflicts so as to determine the relationship of such successes and failures to changes in U.S. national security strategy. The link between public opinion and a possible change in strategy by the NCA in an OOTW conflict will be measured by the reports of the Gallup polls. The correlation of these changes in strategy with public opinion could lead an observer to believe that the will of the U.S. population could be broken due to a tactical failure which resulted in a large number of casualties. 
THE STRATEGIC ENVIRONMENT FOR OOTW

The Political Perspective

The American policy of injecting light forces quickly into an OOTW environment to stabilize the situation, while not accompanying these forces with a heavy component which could project an international image of overt aggression, may present an opponent with a tactical advantage and an opportunity to effect the strategic course of action. "The LID decision was driven primarily by a military strategy based on a capability to deter aggression before it reached an escalatory phase-crisis response."2

Light infantry forces are possibly more vulnerable in an ooTw because of their reduced force protection. In conventional operations light infantry would deploy in terrain best suited to its capabilities. In oOTw, the light infantry may not have positional advantage and could possibly become involved in a situation where the terrain was chosen by the enemy. The enemy could consequently inflict numerous casualties on the light infantry forces with the intent of influencing U.S. strategy by testing the National Command Authority's (NCA) resolve. U.S. and world public opinion can become instruments to influence U.S. strategy .

U.S. combatant troop involvement is a tough and unpopular decision, because most peacemaking(and peacekeeping) situations do not directly involve vital or major U.S. interests and because these situations place 
U.S. forces in danger for long periods of time. ${ }^{3}$ This translates into a danger for U.S. Army light forces since they are the force within the Army which is earmarked to conduct these OOTW missions. "Peacekeeping also requires soldiers who know how to protect themselves in small units(fight if necessary), but (who) do not exhibit an offensive capability that would endanger the peace process."4 Granted, a peacekeeping or peacemaking force should not possess a large offensive capability that could project an adverse image to the international community and to the sides involved in the conflict; but this does not mean there cannot be a significant increase in certain items of equipment or procedures that would increase force protection.

The NCA has four major requirements that must be met before military force is used. First, the costs and risks of any engagement must be weighed so as to determine to what extent national interests are at stake. Second, while the U.S. will seek the help of allies or of multilateral institutions, the U.S. is prepared to act alone. Third, the following questions are examined: Have we considered non-military means? What type of U.S. military capabilities are required? Do we have the support of the American people and their elected representatives? Do we have a way of measuring success or failure; and do we have an exit strategy? Finally, the engagement must meet reasonable cost and feasibility thresholds.5 Realistically stated, "with 
any long term committment comes the baggage of cost, casualties, conflict termination pressures, mission success criteria, additional mission requirements, and the possibility of eroding public and congressional support." 6 The OOTW conflict presents the U.S. strategic planner with a complex dilemma. When the National Command Authority commits the U.S. military into OOTW conflicts the U.S. public may not support the action. U.S. public opinion is probably ambivalent and opinion polls could reflect this ambivalence. Partisan politics and the activities of the press could act to confuse the public and strain the relationship between the $\mathrm{NCA}$ and the public.

\section{The Military Perspective}

Current OOTW doctrine originated in low intensity conflict doctrine developed from earlier U.S. experience. The U.S. involvement in Vietnam has acted as a base of knowledge for U.S. thought. Decentralized forces applying a variety of flexible options in order to influence the conclusion of a conflict in coordination with other instruments of power is the essence of low intensity conflict doctrine. These low intensity conflict operations and now OOTW missions always involve complicated rules of engagement(ROE), large numbers of civilians and the need to preserve and often to reconstruct a national or city infrastructure. ${ }^{7}$

The conventional battlefield orientation of U.S. light forces may not be suited to OOTW conflict. OOTW are a 
spectrum of military operations which range from humanitarian assistance to peacemaking and which may involve conflict or the threat of conflict. The U.S. Army is trained to fight opponents in all types of combat with an emphasis on the synchronization of seven battlefield operating systems. OOTW operations frequently require a minimal use of force to resolve the problem. This emphasis on minimal force demands a military response by the U.S. which is capable of stabilizing the current situation and reducing further escalation by potential adversaries. An underlying and significant caveat for U.S. operations is to resolve the problem quickly and cheaply.

U.S. light infantry is specifically designed for the contingency missions which can arise in an OOTW environment. The combination of the minimal use of force and a unit capable of presenting that force has resulted in the increased reliance on light forces as the U.S. solution to OOTW crises. These light forces are easier and less expensive to move strategically when compared with heavy forces and consequently can provide a quicker response in an OOTW situation where a conflict is ongoing or possible.

The forces deploying into the area of conflict are most vulnerable during the initial stages of the lodgement. This vulnerability exists whether airlift or sealift is used to deploy the force. A potential enemy during an OOTW crisis could perceive that public opinion is most pliable after the conflict has begun. This elasticity starts before the 
decision to commit U.S. forces to a conflict and continues until there is an actual or perceived success in the operation. If success is never perceived, then public opinion could sour and a clamor for withdrawal from the situation may develop. An OOTW opponent may have any level of technological sophistication and weaponry available. Infantry throughout the world are the most symetrical force on the battlefield. This symmetry is most notable in a jungle or urban environment where observation and fields of fire are drastically reduced. A prudent enemy commander can circumvent current technological innovations for U.S. infantry by dictating the terms of the engagements.

The American military has the most advanced technologies in the world to assist its forces in conducting their missions. U.S. light infantry has the assistance of night vision devices to enhance its ability to conduct continuous operations. Rotary wing aircraft add mobility to light infantry operations and are a lethal fire-support asset. Advanced communication equipment facilitates command and control while space and aircraft based systems add a whole new aspect to intelligence gathering. However, in a small and seemingly insignificant conflict, complexities can arise that neutralize these technologies.

An irregular enemy force can achieve parity with the U.S. by their intimate knowledge of the terrain and environment. The enemy commander can use this knowledge to accept combat in confined terrain, such as an urban area 
with numerous noncombatants present, thereby denying the U.S. light infantry its advantages in technology. The enemy objective may not be to seek decisive victory but instead only to generate as many casualties as possible, creating a variation of attrition warfare. Engagements may be aimed at influencing U.S. public opinion to bring internal political pressure on the NCA. These casualties will play on the fears of the public and the government at a time that the government is seeking the support it needs for its initial decision to intervene.

In some OOTW where the U.S. has become involved, general conflict had not yet begun. The interventions in Panama and Grenada, along with our most recent entry into Haiti, are examples of entering an OOTW before general conflict has started. The common denominator in these actions is the initiative that the U.S. has because of surprise and the early elimination of the enemy's potential combat capabilities and consequently of the enemy's will. The transition from a combat operation to a post conflict operation is generally very quick and the emphasis shifts from peacemaking to peacekeeping and nation building.

\section{The Light Infantry Perpective}

The light infantry forces of the post cold war era have created as much controversy as they did during their development and implementation in the early 1980's. The scramble for roles and missions by the services revived the debate in the U.S. Army over the force structure 
and resourcing issues. This debate was caused by the demise of a large scale threat and a motivation for institutional survival as the U.S. military was forced to drawdown.

There are essentially two diametrically opposed points of view on light infantry. The first is that the light infantry is the force of choice in our new security era. Operations Other than war is the spectrum of operations and contingency missions that the light infantry were specifically designed to counter successfully. The other point of view is that light infantry is and has always been an insufficient force to deal with the lethality and mobility of modern combat operations. A component of this arguement is the view that light infantry is a redundant force when U.S. Marine Corps and Special Operations Forces are considered. Consequently, light infantry according to this view are an unnecessary use of resources. 8

The force projection strategy of the United States and the rapid deployability of light infantry fully complement each other. The light infantry gives the U.S. an ability to decisively engage in conflicts short of war in an inexpensive manner with regards to deployment and sustainment costs. The light infantry acts to conserve heavy units for major regional contingencies while the light infantry is conducting the OOTW mission. The shift to OOTW clearly provides the light infantry with the niche it was designed to fill. 
The controversy over the initial development of light infantry divisions revolved around the utility of the LID in mid to high intensity combat environments, particularly in NATO.9 Much of this argument has fallen away since the threat of general war has decreased dramatically. The termination of this controversy has focused attention on the second argument that light infantry is inadequate to cope with combat operations because of built in weaknessess.

A current trend in the Light infantry community within the U.S. Army is the thought that the light infantry, particularly the light infantry division(LID), needs restructuring. This is an effort to make the light infantry more capable for future conflicts and has grown out of the criticism of light infantry inadequacies. The three areas that are of the greatest concern are lethality, sustainability, and tactical mobility. ${ }^{10}$ The functions of the light infantry division were spelled out in the 1984 white paper on the LID and they are twofold: to execute low intensity conflict (LIC) missions worldwide, such as counterinsurgency, peacekeeping and contingency operations, and to rapidly reinforce forward deployed forces in NATO and the far east. 11

The prevailing positive view on light infantry is best expressed by a student from the U.S.Army War College:

LIDs brought to the National Command Authority a capability with strategic agility, deployability, and flexibility that could be employed across the spectrum of conflict, anywhere in the world. A capability that on one hand was relatively inexpensive and non- 
offensive in nature; yet, which provided a source of strategic deterrence, crisis response, and national resolve when deployed in harm's way. 12

Although the IID is designed for offensive tasks, the light division can conduct defensive operations. These defensive operations fail to capitalize on their special capabilities, specifically, their superior tactical mobility in close terrain with an emphasis on stealth and offense. Tying the light infantry to fixed points increases their vulnerability and robs their commanders of the available skills that act as combat multipliers because such defensive missions are essentially battles of attrition. 13 The LID can provide a robust defense on a short term basis, but its commander must recognize that its' survivability and utility diminish the longer it remains in that role.

Although the U.S. Marines are often employed with a light force structure, they possess a flexibility in their organization to provide a more combined arms approach to contingency operations. The marines use tanks and light armored vehicles in a general support role and give these forces to marine infantry battalions. The amphibious vehicles that the marines possess are also lightly armored and provide mobility and protection to marine infantry. The U.S. Marines support certain OOTW missions; however, peace support operations are viewed as the U.S. Army's mission. 


\section{Light Force Tactics}

An important consideration for having light forces in a force projection national strategy is that the light forces requires less of our precious airlift resources to deploy from Conus to the area of operations. The light division was created as a balance between deployability and strategic strength to achieive strategic and operational surprise. ${ }^{14}$ Surprise has always been an important consideration in military operations, but in an OOTW conflict it is only a small part of the equation for success. Deploying quickly only addresses the problem of getting to the theater and involves only the minimum force necessary to complete the mission. The tactical problem of protection, survivability, and mobility in the conflict will determine success or failure. 15

Light infantry is designed to seek out and destroy the enemy on his own terrain, using initiative, stealth and surprise. ${ }^{16}$

The LID is composed primarily of foot mobile light fighters. The Brigades and Battalions are organized, equipped, and trained to conduct combat operations against light enemy forces on any type terrain and under all environmental conditions. Constant, aggressive, offensive actions cause the enemy to react to the activity of the light force... These characteristics are necessary not only for success, however just as important, they are essential for survival of the force.17

There is a dangerous assumption among some in the U.S. military that the enemy is neither capable nor active and hence will not use any of these attributes. The enemy in an OOTW conflict opposing the U.S. light forces has no choice 
but to use his initiative, stealth, and surprise if he wishes to prevail and continue the fight. When the fact of U.S. air control is taken into account, the enemy is forced to couple those techniques with the intimate knowledge of the terrain to seek at least parity with U.S. Iight forces before initiating combat. The enemy is thus potentially a tough opponent from the outset.

There is a symmetry amongst light forces regardless of which country fields the force. "A formation's firepower, mobility, or sustainability, and therefore its strength or deficiencies are relative to that of the enemy at any particular point in time."18 The average assault rifle and hand held grenade or missile launcher are practically equal in performance capabilities and effectiveness.

Technological advantages produce a small difference in the operations of fielded light infantry forces. Passive and thermal night vision equipment, lightweight protective body armor, and secure communications equipment are the primary technological items that give U.S. light forces a tactical edge in continuous operations, personnel survivability, and command and control. Because of the nature of the conflict; however, these items do not act synergistically to create a significant asymmetry between opposing light forces in an OOTW conflict.

Air mobility gives the U.S. light infantry a high level of quickness to move about the battlefield. Attack aviation also provides a formidable means of direct fire support. 
The OOTW environment can pose a significant threat to helicopters. The small arms that an opponent in OOTW may have may not be detected by the helicopters until they are fired upon at short range. Small arms cannot be suppressed except with direct fires and if the firers wait to engage at close range then the helicopters are in immediate danger.

The light forces' night vision capability is essential to continuous operations; however, current levels of this technology with light forces have tactical shortcomings. The night vision capability of U.S. light infantry at the company level is based on a technology called image intensification. These devices have moderate ranges and their performance is proportional to the level of light available. Any atmospheric or battlefield condition such as rain, snow, fog or vegetation decreases their effectiveness. The more ambient light that is available the better these devices function; however, a bright light (muzzle flash, illumination round, or explosive flash), causes a condition called blooming which renders the device ineffective for different lengths of time depending on the brightness and duration of the exposure. Blooming sometines produces permanent damage in early model devices. 19

The defender has the advantage in night operations when night vision devices(NVD) are employed. Because the defense is generally stationary, every NVD that the defender has can be used to detect and engage the attacking force. The majority of an attackers night vision equipment, 
specifically the thermal imagery, has a reduced capability because it is large and cumbersome. This reduced capability comes from the nature of the movement that the attacker must make to accomplish a mission in which the large stationary thermal imagery NVD's are used to guide the attackers wearing short range image intensification devices. "What develops is a situation where a defender with only a modicum of (low quality) night vision equipment can visually dominate the area he defends, while the attacker who may have a quantitative and qualitative edge in equipment can only use a limited amount of it and is at a disadvantage."20 The other aspect that can offset an attackers advantage in night vision equipment is the defender's intimate knowledge of the terrain; even if he has absolutely no night vision capability. This was part of the tactical problem in Somalia on 3-4 October 1993 when the Somalia militia, without NVD, fought U.S. light infantry during the hours of darkness in the close quarters of urban terrain. The short ranges within the urban areas and the masking effects of buildings, coupled with the somali knowledge of the area, caused fire engagements to occur at short ranges. This gave the U.S. forces only a nominal advantage.

THE OOTW CONFLICT

Historical Perpective

The review of two historical examples will illustrate the value and effectiveness of light infantry forces in an OOTW conflict which does not escalate into conventional 
warfare. The two examples are the U.S. Marines conducting a peacekeeping operation in Beirut in 1983 and the U.S. Army in a peace enforcement operation in Somalia in 1993. Although the U.S. Marines are not designed as a light infantry force, they were task organized essentially as light infantry for the Beirut operation and hence can be used as an example in this context. A review of the training and doctrine of the forces prior to their commitment into the OOTW conflict will determine their preparedness for the operation. This review will highlight the differences in procedures by the two forces in an OOTW peace support mission.

Beirut and Somalia are examples of failure in OOTW. The failures involve a basic shift in the OOTW mission of the light forces, while the light force's basic structures and procedures for the original mission did not change and they subsequently suffered unexpected casualties due to this change in strategy. An analysis of the casualty situations should determine operational similarities which presented the enemy with the opportunity to succeed with one violent action. The differences between the operations will help illustrate the reasons for success or failure in OOTW.

An army in peacekeeping and peace enforcement missions has a potential for conducting combat missions and therefore an army must approach these problems with the foreknowledge that combat may occur. The emphasis during these missions is on diplomatic efforts and this prevents the military from 
using offensive operations because of the complications that would arise. The nature of these operations place forces in a defensive posture because no enemy is available. Security and protection are the primary concerns for the peace support mission and the historical examples are reviewed from this perspective.

Beirut

On 29 September, 1982, the 32nd Marine Amphibious Unit (MAU) landed at the port of Beirut and occupied defensive positions in the vicinity of the Beirut international airport between the Israeli defense forces and the population of Beirut. The Israelis' had invaded Lebanon in June. After their offensive reached Beirut a stalemate developed between all the warring factions. The U.N. engineered a ceasefire and calculated that there was a possibility of reestablishing the legitimate government of Lebanon. The U.N., under U.S. leadership, sought to provide the Lebanese government and armed forces with the security umbrella they needed to regain control. ${ }^{21}$

When U.S. Marines entered Beirut the environment was not hostile. The marines were welcomed and treated well by the majority of the Lebanese population. In establishing positions within the wartorn sections of Beirut international airport they were unhindered by any faction. The Marines occupied the airport to keep it operational and thereby made the airport serve as a symbol of normalcy. 
The major buildings at the airport were occupied from the outset for a number of reasons: the large buildings had good fields of vision from the rooftops, they provided good command, control and logistics locations because they were in the center of the marine sector and, most importantly, the buildings were constructed of reinforced concrete and gave protection to their occupants from direct and indirect fires. The building occupied by the battalion headquarters was the most ideal of all the buildings available. Although the marines had entered what appeared as a benign environment they nevertheless took readiness precautions. 22

The battalion landing team's headquarters building quickly became a hub of activity in the marine sector. All the command and control elements were located in the building except for the MAU Headquarters. The roof of the building became crowded with radio antennas to facilitate the communications between ship and shore, as well as within the MAU. The building was increasing isolated from the rest of the airport activities as the security situation worsened. An estimated 20 tons of barrier materials were emplaced in and around the building from 29 May to 23 October. ${ }^{23}$

During the next year the environment around the Beirut international airport changed dramatically for the marines. Confrontations occured between the Israeli defense forces and the marines during the winter and in March five marines were wounded by a terrorist's grenade. On 18 April 1983, 
the U.S. embassy in Beirut was destroyed by a large bomb killing some 60 people, 17 of whom were U.S. citizens.24 The marines were now responsible for the security of all Americans in Lebanon. Renewed fighting took place between the Christian Lebanese and the Druze militias and continued sporadically through August. ${ }^{25}$ The Israelis and Syrians maneuvered to gain political advantages. The third rotation of the MAU occured in late May 1983 and at the same time the marines began combined patrols with the Lebanese armed forces.

The situation deteriorated slowly through the summer of 1983 to the point where the original peacekeeping goals had become obsolete. The U.S. forces thought they were neutral because they supported the Lebanese government, but in the midst of a civil war the Lebanese government was viewed by other factions as just another adversary. The U.S. forces were not viewed as neutral and they consequently became a target. Indirect fire from mortars and artillery, along with sniper attacks, continued to take their toll.

On 28 August 1983, the marines returned fire for the first time and on the 29th, marine artillery silenced a battery from one faction after two marines had been killed by a mortar attack. ${ }^{26}$ The situation then deteriorated rapidly through the month of September. The Israelis withdrew to the south and fighting increased between the factions to control the void left by the Israeli withdrawal. The NCA directed an emergency resupply of ammunition to the 
Lebanese armed forces. The battleship USS New Jersey Surface Action Group arrived off Lebanon and a ceasefire was engineered on 25 september. 27 The ceasefire officially lasted until mid-October, but throughout this time sniper and indirect fire continued against the marines killing two more on 14-16 october.28 on 23 October 1983, a terrorist fanatic drove a mercedes truck loaded with explosives through the barbed wire entanglement around the BLT headquarters and into the building. The explosives were detonated and the resulting explosion killed 241 soldiers and marines and wounded 100 others. ${ }^{29}$ The NCA reinforced the U.S. forces in Lebanon and they remained for another four months; however, stricter operations and tighter security precluded any other significant incidents except for the occasional casualty by a mortar round or sniper. The circumstances surrounding the incident were analyzed in depth to determine why such a immense vulnerability existed. An investigative board determined that the original peacekeeping mission given to the marines became null and void considering the general deterioration of the situation. ${ }^{30}$ The board also recognized that the initial instructions did not specify which actions that could or could not be taken with the Lebanese armed forces and that subsequent actions by the marines with the Lebanese forces eliminated their neutrality.

The board also discovered that the normal operation of the airport caused a security situation that was unmanagable 
at best. The number of vehicles and civilian personnel going in and out of the airport made collecting intelligence against the marines easy; however, marine intelligence gathering efforts were ineffective. The marines relied almost exclusively on Humint assets and the board found that: "the USMNF was operating in an urban environment surrounded by hostile forces without any way of pursuing the accuracy of data in order to head off attack." Finally, the grouping of over 300 servicemen in one location with severely restrictive ROE, compounded marine vulnerability and presented a lucrative target.

\section{Somalia}

On 9 December, 1992, the U.S. Marines conducted an amphibious operation near the city of Mogadishu, Somalia and this heralded the start of Operation Restore Hope. ${ }^{31}$ Operation Restore Hope was the U.S. action under U.N. sponsorship to restore order in a country ravaged by anarchy. The ultimate purpose was to reestablish an infrastructure within the country to halt the thousands of deaths from starvation. The U.S. forces started in Somalia as part of a peace enforcement operation.

The U.S. Army's 10th Mountain Division, a LID, landed its first troops in Mogadishu on 13 December, 1992 to begin the major peace enforcement operations in Somalia. ${ }^{32}$ U.S. forces were accompanied by other U.N. forces and together these forces moved to secure relief distribution sites. From 17 December to 17 February, these combined forces 
expanded their areas of responsibility to include securing zones called Humanitarian Relief Sectors(HRS). Support and security for Non-Governmental Agencies(NGO) were also conducted. 33 During these operations the emphasis was to uncover and seize different factions' weapons caches. Somalis were encouraged to turn in their weapons. The stated U.S. policies toward the feuding Somali factions were no visible weapons, unauthorized checkpoints, bandits, or technicals (a civilian truck modified to carry a large machine gun).${ }^{34}$ The U.N. coalition forces were greeted with acceptance and viewed as a stabilizing force by most of the Somali population. As the U.S. light forces secured different areas they established security checkpoints and defensive positions with units on constant alert.

During the first two months of the operation incidents gradually increased. U.S. and other forces conducted a series of air assault operations to secure small towns and key points in the vicinity of Mogadishu to deny the warring factions freedom of movement. On 6 January, Somalis fired on a U.S. convoy as it passed by the compound of the most powerful clan leader, General Aideed. The following day U.S. Marines stormed the compound without bloodshed. On securing the compound they confiscated weapons and forced the clan members to leave. A sniper killed a U.S. soldier on the 13th, this was the the first U.S. death. 35 U.N. forces concentrated on an intense effort to rebuild the country's infrastructure during the rest of January. On the 
26th of January a flight of AH-1 attack helicopters destroyed a convoy of technicals in the vicinity of the town of Kismayo. General Aideed did not command these technicals. 36

The pace of events increased throughout February as the U.S. forces began their redeployments back to the United States and U.N. forces gained control. As the U.S. began to drawdown a Somali faction under its leader Colonel Morgan seized the city of Kismayo. Heavy fighting broke out with another faction commanded by Colonel Jess, an ally of General Aideed. 37 The U.S. Army forces commander, Major General Arnold, gave Col. Morgan an ultimatum to leave Kismayo the next day. On the 24 th, General Aideed organized a large anti-American protest in the streets of Mogadishu without incident. Colonel Morgan also agreed to withdraw from Kismayo on the 25th, but different hostile actions wounded four marines in that same 24 hour period. 38 General Aideed was given responsibility for the attacks although this report was never confirmed. Both Morgan and Jess turned in large numbers of weapons on the 27th of February and the situation appears to have stabilized until early June 1993.39 The opposing factions slowly formed into a loose coalition.

General Aideed became the enemy to U.N. success in Operation Restore Hope and therefore the U.S. military operations concentrated on his capture. The U.N. operation reduced General Aideed's influence by slowly disarming his 
forces and driving them away from key points of the Somali population. 40 General Aideed's forces conducted an ambush against a Pakistani light infantry unit on 6 June, 1993, killing 24 Pakistani soldiers and injuring many more. The U.N. reacted by declaring a resolution to arrest and detain those responsible for punishment. 41 A command detonated mine killed four U.S. military policeman while they were patrolling in their vehicle on 8 August and this was also attributed to Aideed's forces. U.S. neutrality had ceased and the war against General Aideed was now official. The scope of the overall operation had changed entirely for the U.S, but the type of force in the fighting did not change. The U.S. light forces still in Somalia were continuing to conduct a peace enforcement operation, while U.S. special operations forces were deployed to Somalia to conduct peacemaking operations. On 22 August, the advanced party of a special operations task force, task force Ranger, arrived in Mogadishu ready to conduct combat operations against General Aideed. The force included approximately 16 helicopters from task force 160(army special operation aviation), a company of Rangers and a Delta force unit. 42 These elements represented the elite of the U.S. light forces. The main part of the force arrived at Mogadishu on 26 August and while they were assembling a Somali mortar round was fired at the airport wounding five task force soldiers on the 29th.43 The first casualties of the new war were Americans. The task force conducted numerous 
operations between 30 August and 21 September with mixed results. Their primary method of operation was with swift and aggressive air assault raids to catch the Somalis by surprise; however, the element of surprise was eventually lost because they had established an identifiable pattern on how they prefered to conduct operations. 44

The U.S. effort to capture General Aideed proved to be a very challenging mission. Aideed had gone into hiding and was constantly moving to avoid capture. His support from many Somalis (who had began to identify with Aideed) and his intimate knowledge of the territory forced Task Force Ranger to alter their plans. The task force began targeting Aideed's subordinates.45 A Colonel Guimale had devised a low tech plan to counter Task Force Ranger's operations and force them into a battle where the two opponents were on equal terms. Guimale spread his forces around Aideed's major command locations with soviet made rocket propelled grenade launchers as the primary weapon against U.S. helicopters. The militia units were prepared to move to any location as quickly as possible to gain a numerical advantage over any U.S. action. The command and control was by small radio. 46

On the October 3, 1993, Task Force Ranger headquarters received intelligence that General Aideed and many of his most trusted subordinates were in a rundown building near the Olympic Hotel on the other side of Mogadishu. The Task Force was prepared for just such a contingency short notice 
mission to capture General Aideed. The unit had prepared for every eventuality, including the shooting down and rescue of personnel from helicopters and the rescue of forces in enemy territory by vehicles. 47 The U.S. commanders decided to execute the mission unilaterally because of security reasons; the U.S. was not going to take the chance that Aideed may be warned.

The mission on 3 October, 1993 began as a daring daylight air assault raid into enemy held territory and ended as a disaster for the reputation of the U.S. forces. A small special team landed in helicopters and captured many Somalis in the building, to include two of Aideed's most senior officers. ${ }^{8}$ A truck convoy moved simultaneously to link up with the soldiers who went in by helicopter. A series of events occured to thwart the operation. A helicopter supporting the mission was shot down by a rocket grenade enroute to pick up the team and its captives. The remaining helicopters were also turned back by hostile fires. 49 Colonel Guimale received word of the attack and ordered militia units to concentrate on the Hotel and the downed helicopter. 50 A second helicopter was shot down by a rocket grenade and crashed away from the first helicopter. 51 Two desperate and deadly battles developed out of supporting range of each other around the two downed helicopters.

The U.S. commander was forced to use all three of his rescue contingency plans to save his forces. A combat search and rescue helicopter with fifteen soldiers and the 
Rangers and Delta personnel moved with their hostages to the first crash site. A vehicle mounted quick reaction force (QRF) from the 10th Mountain Division prepared at the airfield for a possible rescue mission. 52 The search and rescue helicopter dropped the fifteen soldiers at the first crash.

The U.S. truck convoy moved from the hotel to the first crash site but became lost in the city streets only to end up back at the hotel. The convoy suffered killed and wounded casualties including some of the prisoners. The convoy reportedly came under fire from almost every intersection it crossed. The truck convoy was then ordered back to the hotel and escaped the rest of the fighting. 53 The force remaining at the hotel moved by foot to the first crash. The fighting raged from house to house as the Ranger platoons moved through the streets. Both sides suffered casualties, but the Somalis were prepared to lose them whereas the Rangers could not afford them. The American commander committed the QRF to the rescue effort but the QRF quickly became involved in a firefight that lasted thirty minutes. The force retreated after using almost all of its ammunition. 54

The battle at the second crash site ended quickly. A helicopter dropped two Delta Force soldiers 100 meters from the wreck in an open area, but they became disoriented in the maze of shacks. While the pilot was pointing out the direction of the crash to the soldiers on the ground, a 
Somali rocket grenade damaged the aircraft and wounded two soldiers. The pilot managed to crash land the helicopter in friendly territory. At the second crash, the two Delta Force soldiers and a wounded pilot fought to the last. Only the wounded pilot survived and the other five U.S. soldiers were killed. 55

The battle continued to rage at the first crash site as more of the Task Force Ranger units arrived on the scene from the hotel. Colonel Guimale wanted to use mortars against the U.S. units, but decided against this action because of Somali women and children that were in the same buildings the Rangers were defending. This incident raised additional controversy over the U.S. forces using the civilians as hostages. 56 The QRF assembled to attempt another rescue. The U.S. commander of Army forces in Somalia requested the use of Pakistani and Malaysian armored vehicles. The assembled force had four Pakistani tanks and twenty-eight Malaysian armored personnel carriers(APC).57 Another light infantry company from the 10 th mountain division fought its way to the first crash while the armored column fought its way to the second crash. Both units suffered casualties enroute; however, Somali resistance was waning after almost eight hours of combat. The infantry company linked up with the Rangers at the first crash site and the armored convoy moved through the second crash site to confirm that there were no survivors. The armored formation moved on to the first site and then 
all the units returned to friendly territory. 58 within a week, an armored task force and additional soldiers with attack helicopters were in Somalia to conduct peacemaking operations. ${ }^{59}$ The situation again stabilized as talks between General Aideed and the U.N. resumed. The U.S. was out Somali by the end of March.

The Somalis suffered almost eleven times as many casualties in killed and wounded, but the perception of failure by the U.S. public was unavoidable. The primary reasons were the complexities of fighting in confined city streets against a determined opponent. The two sides fighting in the city streets were equal once the U.S. helicopters left. 60 secondly, a combination of peace enforcement and peacemaking operations gave mixed signals to the Somalis. The somalis saw only the combat operations against them and these events acted to unite them. The U.S. did not significantly change the type of forces in Somalia once the mission had changed.

\section{Historical Synopsis}

U.S. light infantry have conducted numerous peace operations. Light forces can achieve a high degree of success and minimal casualties in a peacemaking operation where the internal conflict in the occupied country has not yet occured. Operations in Grenada in 1983 and in Panama in 1989 were at the extreme end of the peacemaking mission. The strategic objectives were to reestablish a country's legitimate government and eliminate an external influence 
hostile to U.S. interests. The U.S. initiated the armed conflicts and achieved surprise at the strategic, operational, and tactical levels. The opposing military forces were quickly overwhelmed. The rapid transition from peacemaking, i.e. conflict, to peacekeeping and postconflict operations combined to diffuse international opinion and national anxieties. The rapid success of the operations resulted in their acceptance by American public opinion. Public opinion therefore had no part in the strategic decision to conduct or continue these operations.

The use of light infantry in peacekeeping operations, where the conflict had degenerated into combat between different factions, have not had favorable results. The operations in Beirut, Somalia, and Bosnia are all examples of operations where anarchy existed. The U.S. and U.N. assumed a neutral role in these conflicts and hence could not conduct any overt aggression against any side. The U.S. or U.N. ran the risk of being perceived as siding with one of the competing factions and therefore lost the protection of neutrality. In Beirut and Somalia the light forces conducted offensive operations under light force doctrine as if they were waging general war. 61

The problems in these conflicts all have common denominators. Each of the situations had numerous factions struggling for control and a large civilian population vulnerable to the violence. Most of the fighting between the different groups occured in and around urban terrain. 
The U.S. or U.N. forces were eventually viewed as opponents by at least one faction and were considered legitimate targets. This situation usually occured because of the perceived interference in the situation by the external forces as they were trying to accomplish their tasks. At the strategic level, the missions that the U.S. and U.N. forces received were open-ended; there were no well-defined endstates or clearly established conditions for success.

When the U.S. or U.N. forces initially intervened, the conflicts were in a benign state with active ceasefires. Hence, the arrival of external military forces went unopposed. Although the ceasefires were externally engineered, the antagonists in these conflicts actually stopped fighting for their own internal reasons. The ebb and flow of these conflicts provide ample windows of relative inactivity by any side. Except in those cases in which one side was supported by an outside source, neither side had a greater combat capability; hence, all the factions usually peaked in their combat capability at approximately the same time.

\section{COMPLEXITIES FOR FUTURE OOTW}

\section{Current OOTW Considerations}

The different points made with regard to what light infantry provides strategically are all factual; however, in an OoTw where conflict is ongoing or likely, national resolve may be the weak link. When the light infantry 
concept was first developed the issues of national will, national survival and vital interests were closely connected in the struggle between the superpowers in in the third world arena. In contrast, a modern ooTw operation is a stand-alone conflict and consequently becomes a media event. Although the cost in money and resources expended is of some concern, the primary worry by the public is the cost in lives of U.S. soldiers.

One phenomenon which exists in third world conflicts is the savagery and ferocity which accompanies the fighting. The fighting is almost always generated by cultural, racial, religious, and economic strife within a country. The combatants are people who often place little value on human life. Once the U.S. or any other country places their forces into these conflicts as either peacemakers or peacekeepers, these soldiers are now subject to the acts of irrational individuals. The likelyhood of confrontation is almost assured if the peacemakers or peacekeepers actively pursue their assigned tasks.

"It is fundamentally clear that there is no single force which adequately meets all battlefield requirements, rather it is a mix based on METT-T." 62 This statement is readily accepted by military planners for combat operations, but is not considered relevant during the planning and execution of a peacemaking or peacekeeping operation. This oversight is partly due to the lack of a formidable threat which could significantly damage the U.S. force. Units do 
not face the possibility of annihilation in an ooTw the way they do in mid-to-high intensity combat and this fact can create a more relaxed attitude. This relaxed attitude in the light force securing the Beirut airport resulted in a lack of security which increased their vulnerability.

The Nature of Combat in OOTW

The urban environment has become the epicenter of struggle in post cold war conflict. Many of the combat multipliers, i,e. artillery, close air support, electronic warfare, and the speed and shock effects associated with rapidly moving mobile forces are reduced or eliminated in urban areas.63 The two types of urban combat are high intensity combat associated with general war and low intensity combat which is commonly found in OOTW. The entire focus of an OOTW may center in a city whereas a general war rarely focuses on one urban area. For example, the majority of the fighting in the former Yugoslavia has centered on cities and towns. 64

An indepth analysis of urban warfare is beyond the scope of this study; however, a review is necessary to explain the most likely and dangerous conditions for future OOTW conflict. Urban combat is the only type of combat where the tactical and operational levels of war can blend into a single level because ground combat now has a three dimensional quality. The constrictive nature of urban warfare is the cause of this phenomenon. "Operational depth in a predominantly rural environment is likely measured in 
the tens or hundreds of kilometers; in a city, such depth could be single digit numbers of kilometers or several city blocks." 65

OOTW conflict and urban combat will become almost synonymous in future operations. The conflict in OOTW often revolves around control of populations. The protective capabilities of urban terrain, combined with the increased strength of the defense, allows a small force to combat a larger more sophisticated unit on an almost equal footing. Technological advantages that either side may possess are often negated.

Training of light forces is currently inadequate for OOTW conflicts in cities. "Army commanders train hard to synchronize their combat assets and then in an OOTW many of those assets are no longer available."66 Indirect fire systems are usually not allowed. In general war large caliber weapons systems are used to make entrance holes into buildings or reduce an enemy position; however, the ROEs in OOTW do not allow such methods because of the unacceptable collateral damage. The same ROE usually eliminates attack helicopters or close air support. "Large scale military operations aimed at destroying the enemy's fighting capability should not be used. Excessive violence undermines the legitimacy of the party that uses it negating the value of political, economic and psychological actions." 67 
Current U.S. infantry training for urban combat has continued to emphasize combat in a high intensity environment. 68 This type of combat is firepower oriented with fragmentation hand grenades and powerful automatic weapons as the tools of combat.

Firepower in urban warfare is not a significant determining factor. A unit cannot secure an area by observation and fire. Securing buildings requires the unit to physically occupy buildings, rooms, rooftops, and basements while an operation is ongoing. Leaving soldiers, teams and squads to occupy buildings depletes a units combat power. Add to this the requirement to protect and control a civilian population and remove suspects or prisoners and the problems of urban fighting expands exponentially. 69

Entering and clearing buildings are quick and violent drilis that are designed to overwhelm an opponent. This technique is entirely inappropriate for an urban environment in OOTW. The effects of high-powered assault rifles or machine guns go beyond the contested building and endanger noncombatants. Excessive loss in civilian life and property will result from such tactics.

The proper method for clearing a building in OOTW is very similar to the techniques used by Special Weapons and Tactics Teams in large city civilian police forces. The emphasis is on precision, rapidity, and minimum violence. The technique has a small team entering a building and moving together throughout the building to eliminate all potential adversaries. Teams follow other teams to secure cleared areas. Engagements are on identified opponents instead of general suppressive firing. This 
technique exists in U.S. special operations forces and its members train for this event on a regular basis. This type of training is expensive and time consuming and requires a high level of expertise. Other light forces do not generally use this technique and proper training facilities are not readily available.

There is one other factor that hampers U.S. conduct in 0०Tw. A common American trait is arrogance when dealing with a culture less sophisticated than our own. This trait, coupled with an inclination to underestimate the enemy's resolve because no resolve has been displayed at the beginning of an operation, will set the stage for disaster. "The great danger is to underestimate the resourcefulness and resources of the enemy."70 The leadership of a unit must strive to avoid a garrison mentality that will undoubtedly develop in a unit. Dispersion of headquarters, soldiers, and equipment and then adequately securing those assets will eliminate the potential for a high casualty and high payoff target.

THE NATIONAL WILL

National will is the collective influence of a country's inhabitants and represents the fortitude of the population. 71 The American public is an important part of U.S. national will. Public support often determines the success or failure of a political career. The U.S. army has acknowledged the influence of public opinion in is primary doctrinal manual: 
The American people expect decisive victory and abhor unnecessary casualties. They prefer quick resolution of conflicts and reserve the right to reconsider their support should any of these conditions not be met. . . 72

Additionally, the American public makes a collective determination on what are excessive casualties and the media assists in forming this decision. There is a current theory that U.S. public opinion during a conflict actually never desires the withdrawal of the U.S. military from an action once friendly casualties have occured, but instead wants a decisive use of military force. 73 The concept applies to Vietnam, Korea, and operation Desert Shield/Storm in the Persian Gulf and has validity for U.S. involvement in large military operations. However, the connection between a major intervention like Vietnam or Korea to a catastrophe in a small OOTW like Beirut or Somalia is questionable. Vietnam and Korea were conflicts embedded in the cold-war mentality and represented the U.S. strategy of containment. Current OOTW conflict does not have a clear link to U.S. interests and in these conflicts the U.S. is involved for largely altruistic reasons. The U.S. public opinion is a quantifiable part of national will and its effects are relatively easy to determine.

\section{The Gallup Polls}

George Gallup started the Gallup Polls in 1936 at the American Institute of Public Opinion. He was a journalism instructor at the University of Iowa and as a 
member of an advertising firm in 1932 he began using polls for marketing research. Gallup developed the quota sampling polling system that uses representative groups from each part of the population. This method avoided a bias in the final outcome of the poll. When Gallup accurately predicted the details of President Roosevelts victory in 1936, the Gallup polls earned a permanent voice in American politics. The media has also became a fixture in American politics because it helps to mold public opinion. Although the relationship between public, media, government, and national security is outside the scope of this study, modern communications technology has allowed the media to have an immediate effect on public opinion and consequently on national will. Public opinion now acts as another player on national security issues. One author states, "public opinion in the United States regarding national security issues, however, is frequently ambivalent, highly fluid, and often contradictory. $" 74$

The relationship between the military and the media is often quite hostile. This adversarial relationship also has an effect on public opinion. Many military observers observe "a clash between the media and the military as a zero-sum game, where the military wins by keeping secrets and the media wins by revealing them."75 one military author states that "the military must help policymakers explain to the public and press the connections between operations and policy."76 
Public opinion has an ambivalent view towards peace support operations. When asked whether or not the U.S. should become involved in Beirut, Bosnia, Somalia, or our latest intervention in Haiti, the approval rate was, respectively: 51\%, 57\%, 74\%, and $40 \% .77$ The Beirut and Somalia numbers were prior to the casualty situations, while the Bosnia and Haiti numbers are prior to intervention by U.S. forces. The percentages do not represent a majority of the American public. The questions for Beirut and Bosnia were over a U.S. action as a unilateral effort. The Somalia and Haiti interventions had different approval rates, but the questions were different from those concerning Beirut or Bosnia. The questions were should we send "U.S. forces into the African nation of Somalia as part of a United Nations effort to deliver relief supplies there?"78 or "Should the U.S. send forces to Haiti as part of a number of nations or should the U.S. not go at all?"79

Combining the U.S. effort with a United Nations effort added immensely to the approval level for Somalia, whereas, combining the U.S. effort in Haiti with other nations did nothing to improve approval ratings. This change is possibly due to the perception that a coalition had failed in somalia and thus such a coalition was unlikely to succeed in Haiti. The poll results were $64 \%$ and $52 \%$ for Somalia when the public was asked if the U.S. would be able to accomplish its goals with few or no American casualties and whether the U.S. would be able to withdraw in a few months 
as planned, .80 Prior to the Haiti intervention, 56\% expected a certain number of casualties.81 The confidence ratings for both Somalia and Haiti are actually more in line with the Beirut approval statistics. These ratings generally reflect the U.S. public's desire, based on the Vietnam experience, to avoid a military and political quagmire. 82

The two cases in which there was a perceived failure due to large casualties have had a dramatic effect on public approval. In February 1984, 58\% of the American public thought the U.S. made a mistake sending Marines to Lebanon. This was a difference of $7 \%$ with the October rating of $51 \%$; moreover, $74 \%$ agreed that the U.S. should withdraw. 83 when asked the same question in January 1984, 57\% approved with withdrawing U.S. forces. 84 The difference in poll results is undoubtedly from the continued stagnation of the situation in Lebanon. These drastic changes in public opinion inside of two months attests to the malleablity of public opinion.

The case of Somalia is similar to the Beirut example but the change occured much faster because there were no other issues to divert public interest. In October 1993, the U.S. public wanted to withdraw from Somalia with $43 \%$ advocating leaving immediately, while another $26 \%$ wanted a gradual withdrawal.85 The total supporting withdrawal was $69 \%$. When asked whether or not it was a mistake to send U.S. soldiers to Somalia, 52\% agreed. 86 Remember that the 
initial approval rate for going to Somalia was $74 \%$ in December 1992! Oddly, 71\% of those polled approved punishing General Aideed militarily. 87 This statistic goes directly against the statistic for withdrawing. The differences in these statistics show the contradictory nature of public opinion.

The casualty situations in Beirut and Somalia caused the NCA to take more decisive steps in the OOTW conflicts to ensure that no more large casualty situations occured. Both the Beirut and Somalia operations continued respectively for four and five months. 88 The NCA established a definite withdrawal plan shortly after each incident and the U.S. did not divert from that plan. The NCA may not have reacted directly to public opinion, but it is clear they were heavily influenced by public opinion. The NCA concerns were about the direct impact of public opinion on the administration and how such opinion would impact upon the Senate and the House.

\section{CONCLUSION}

\section{The Realities of OOTW}

In those instances where the the U.S. has entered into a peace operation where the belligerents have fought for a lengthy period of time and the conflict has degenerated to the point where atrocities are common events, then the U.S. intervention has an increased chance of failure or perceived failure. The light forces inherent weaknessess in force protection and battlefield mobility exacerbate the effects 
of the environment in OOTW. An adversary in an OOTW conflict who is willing to lose a disproportionate amount of lives to create U.S. casualties will probably prevail in the outcome, because the American public will not be willing to make a continued sacrifice in lives.

The issue of whether or not the conflict involves a vital or even a major national interest give adversaries an opening to influence U.S. national will. Policymakers and military commanders "must communicate the goals of policies and the objectives of military operations clearly and simply enough so that the widest of audiences can envision the ways and means being used to reach those goals." 89

The adversary faces a dilemma when choosing a violent course of action against U.S. forces. The enemy cannot afford to incur too many casualties in one action against the U.S. for fear of increasing resolve in the $\mathrm{NCA}$ and the national will. There is a distinct possibility that the American public may support decisive action and therefore give the NCA the approval to attempt a tactically decisive operation. The goal of the U.S. forces would then change to eradicating any threat to the U.S. forces in the conflict. The longer the OOTW operation, the higher the probability that the deaths of U.S. soldiers and possibly civilians will create a media backlash that could effect the outcome of the operation by causing a change in strategy at the national level. 
The issue of casualties in OOTW provides a complicated situation for the leaders and planners of the force conducting the operation. Numerous inquiries are made over the events and decisions that resulted in the casualties. Those investigations are both official and unofficial and the most troublesome of the investigations will come from the media. The problem with these unofficial investigations is that ongoing operations or knowledge of the details of the operation conducted could provide information valuable for an enemy. The NCA and the military must collectively do their utmost to ensure security. Neither the Government nor the military should ever attempt to hide or obscure the fact that casualties have happened. The facts would eventually surface and the a very destructive backlash would occur.

\section{Conserving the Force}

Force protection is essential to the light force in maintaining combat power and force integrity. In OOTW force protection takes on the added dimension of preserving the entire operation. The final act of using APCs and tanks in a rescue effort in Somalia illustrates the importance of such protection. When the Canadians decided to send a peacekeeping force to Sarajevo, they took a small number of APCs with them. They learned during the operations that many more were needed to protect their force while completing their mission. The commander recommended that all the units coming to Sarajevo were fully mechanized to handle the situation. 90 
Although light infantry is designed to operate unaugmented in urban terrain during general war, it is not viable in urban terrain in OOTW. Force protection of individual soldiers by protecting whole units decreases the probability of mass casualties and denies the enemy of a means to simultaneously effect the deployed force and the U.S. national will. Consequently, the NCA will not feel compelled to change strategy in the OOTW conflict. Combined arms operations in OOTW are also a source of controversy. There are basically four schools of thought for the use of U.S. light infantry in peacemaking or peacekeeping in our new security era. The first is to leave light infantry unchanged in structure and prepare them for mid-to-high intensity combat while using them in OOTW as required.91 The second is to mix light infantry and heavy forces in a light/heavy combination to complement one another in all types of combat situations. This arrangement could be a temporary force package for a specific mission or a semipermanent grouping under a slightly reorganized brigade or division structure. The third is to augment light infantry divisions with light armored wheeled or tracked vehicles in a vehicle pool. This unit acts as a light armored transportation battalion. 92

The final viewpoint is a permanent force which is between heavy and light forces. This middleweight force is a corps or division organization which has mobility and protection through the use of both wheeled and tracked light 
armored vehicles. 93 The unit uses light tanks and armored cars as the primary means for fighting and moving and can successfully fight an heavy enemy force if required. The middleweight force is also envisioned as the force to conduct some of the OOTW missions.

Opponents of augmenting light infantry use any number of reasons not to take this course of action. Light infantry purists state, "as the LID is augmented its nature is changed and it becomes an organization which no longer fights in a manner consistent with the philosophy that governs its existence."94 Although this statement is designed to protect the offensive capability of light infantry, it does not take into account that the OOTW conflict is defensive in nature. A resistance to augmentation does not facilitate an attempt to tailor a unit for OOTW, given that METT-T suggests that armor $\backslash$ mech would increase the light force protection.

Another reason for not placing considerable augmentation in a light infantry division is because of its strategic role. "The role of the LID within the army was to provide rapidly deployable army forces with strategic agility and flexibility."95 Placing any additional augmentation to the LID will significantly reduce the its ability to deploy quickly and economically. This was appropriate during the cold war where hours counted in a major conflict. The new contingencies that could occur do not have such a premium on a large number of forces in a 
minimum amount of time. The emphasis is now on a tailored force with multifacted capabilities and the ability to handle varied situations in the same operation. Airlift assets are now the most valuable strategic asset the U.S. owns and sending a unit that has only a limited capability to a contingency is not making the best use of the airlift or maneuver resources.

There is one other arguement against task organizing light-heavy for oOTw. The heavy forces equipment, specifically M1 tanks and M2 fighting vehicles, are viewed as offensive weapons and could potentially create a politically sensitive issue in a purported peacekeeping operation. The connotation is invasion or coercion instead of assistance and arbitration. In a bona fide peacekeeping operation the armored vehicles are definitely inappropriate. In a peace enforcement or peacemaking operation where the expectation is that fighting will occur, then the best equipment for fighting is required.

Severe resource constraints in the post cold war army preclude the development or major purchase of any new vehicle or system. Yet the U.S. military will still become involved in peace operations. The effects of casualties will still affect the strategy in OOTW while the media will remain a catalyst for public opinion. Service, branch and unit parochialism will continue, while mission creep has become an integral part of OOTW. Commanders and planners for OOTW must think of force protection and adjust the force 
structure as the mission changes, regardless of the type of peace operation. 
$I_{A}$ National security strategy of Engagement and Enlargement. July 1994. Hereafter cited as strategy.

2F.L. Hagenbeck. "The Light Infantry Division: A Case for Greater Robuetness." Unpublished monograph. U.S. Army War College, Carlisle Barracks, Pennsylvannia, 15 April 1993, p 4. Hereafter cited as Hagenbeck.

$3_{\text {Richard Babbit. "Light Infantry Divisions in the New World }}$ Order." Unpublished monograph. U.S. Army War College, Carlisle Barracks, Pennsylvannia, 15 April 1993, p 2. Hereafter cited as Babbitt.

${ }^{4}$ Ibid, p 22.

5strategy, p 10.

$6_{\text {Babbit, p } 28 .}$

7T.R. Milton. "Urban Operations: Future War." Military Review.

(February 1994), p 42. Hereafter cited as Milton.

8 William Garrett. "Army Contingency Forces and Marine Corps Expeditionary Forces: Unique or Redundant?" Unpublished monograph. School of Advanced Military Studies, Ft. Leavenworth, Kansas, 14 May 1993, pp 49-50.

9 Babbit, p 9 .

$10_{\text {Hagenbeck, p } 6 .}$

${ }^{11}$ General John Wickham, Jr. "White Paper 1984 Light Infantry Division." Washington D.C.: Office of the CSA, 16 April 1984, p ii.

12 Babbit, p 33.

13 Zannie Smith. "Light Infantry Division Assessment." Unpublished monograph. U.S. Army War College, Carlisle Barracks, Pennsylvannia, 2 April 1990, p 15. Hereafter cited as Smith.

14 Ibid, p 18.

${ }^{15}$ Ibid, p 22 .

16Ibid, p 28.

17 Ibid, p 4.

18 Ibid, p 18. 
19Jim Menulty. "Night Vision Technology and the Night Attack by Light Infantry." Unpublished monograph, School of Advanced Military Studies, Ft. Leavenworth, Kansas, 19 February 1993, P 15 .

20 Ibid, p 19.

$21_{\text {Report of the DOD Commission on Beirut International }}$ Airport Terrorist Act, October 23, 1983. U.S. Department of Defense, 20 December 1983, p 29. Hereafter cited as Beirut.

22 Ibid, pp 74-75.

23 Ibid, pp 72-73.

${ }^{24}$ Ibid, p 30.

25 Ibid, p 31 .

${ }^{26}$ Ibid.

27 Ibid, p 32 .

28 Ibid, p 40.

29Ibid, p 32.

$30_{\text {Ibid, p } 43 .}$

${ }^{31} 10$ th Mountain Division(L), After Action Review for Operation Restore Hope. Ft Drum, NY: 1993. App. B-1. Hereafter known as AAR.

32 Ibid, App. B-2 .

${ }^{33}$ Ibid, p 11.

${ }^{34}$ Ibid, App. B-4.

${ }^{35}$ Ibid, App. B-5.

${ }^{36}$ Ibid.

${ }^{37}$ Ibid, App. B-7.

38 Ibid, App. B-8

39 Ibid.

40 George J. Church. "Anatomy of a Disaster," Time. October 8, 1993. pp 45-46. Hereafter known as Church.

${ }^{41}$ Ibid. 
42 Rick Atkinson, "The Raid that went Wrong," The Washington

post. January 30, 1994, p A26. Hereafter known as Raid.

43 Ibid.

${ }^{44}$ Ibid, p A27.

45 Ibid.

$46_{\text {Rick Atkinson, "Firefight in Mogadishu," The Washington }}$

Post. January 31, 1994, p A1. Hereafter known as Firefight.

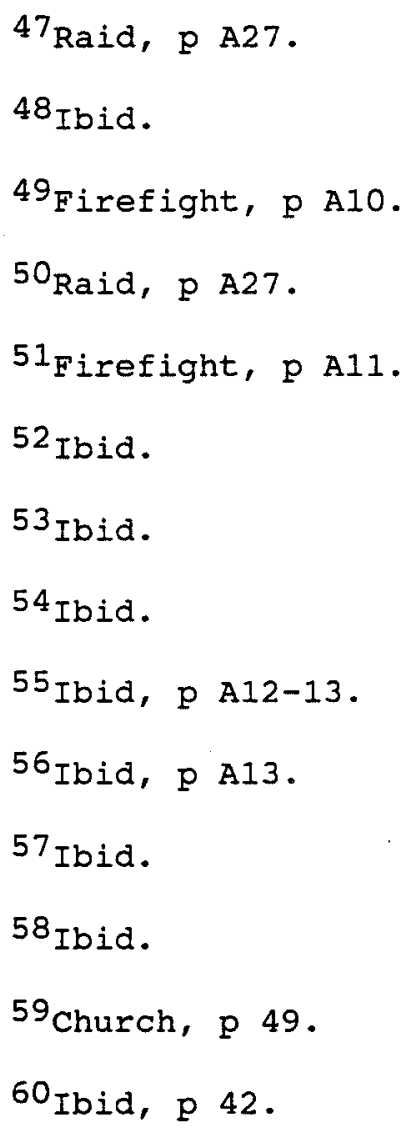


${ }^{62}$ Smith, p 16.

63 Milton, p 38 .

${ }^{64}$ Ibid, p 39.

${ }^{65}$ Conversation with LTC Russel Glenn, School of Advanced Military Studies, Ft Leavenworth, Kansas, 30 November 1994.

$66_{\text {Milton, }} \mathrm{p} 42$.

${ }^{67}$ Ibid, p 45 .

68 John Hunt. "Hostilities Short of War." Miliary Review. (March 1993): 45, p 45.

${ }^{69}$ Milton, p 42.

70 Ibid, p 44 .

$71_{\text {Karl }}$ von Clausewitz, On War. ed. Michael Howard and Peter Paret, Princeton: Princeton University Press, 1984, p 373.

72Department of the Army. Operations. Field Manual 100-5, Washington D.C.: U.S. Government Printing Office, 14 June 1993, p . $1-3$.

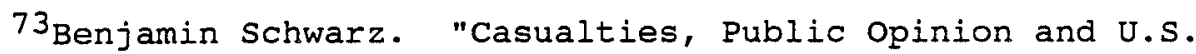
Military Intervention: Implications for U.S. Regional Deterrence Strategies." Santa Monica, California: Rand, 1994, p 25.

${ }^{74}$ Sam C. Sarkesian and John Allen Williams. The U.S. Army in a New Security Era. Boulder, Co: Lynne Rienner Publishers, Inc., 1990, p 42 .

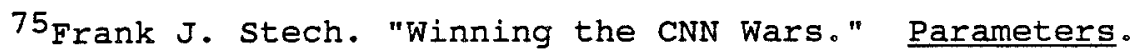
Carlisle, PA: U.S. Army War College, Vol 24, No. 3, (Autumn 1994), p 48. Hereafter known as CNN.

76 Ibid, p 49 .

77 The Gallup Report, Report Nos. 220/221, January/February 1984, p 16; Report No. 329, February 1993, p 12; Report No. 327, December 1992, p 18, Hereafter cited as Report 327; The Gallup Research Library, The Gallup Organization, telephone interview with author, 29 November, 1994. Hereafter cited as Gallup.

78 The Gallup Report, Ed. Leslie C. MCAneny, Report No. 327, December 1992 , p 18.

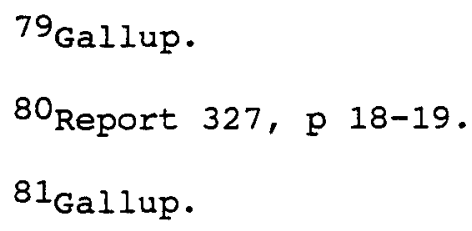


${ }^{82}$ Conversation with Dr. Ernest Evans, School of Advanced Military Studies, Ft. Leavenworth, Kansas, 22 November, 1994.

${ }^{83}$ The Gallup Report, ed. James Shriver, Report Nos. 220/221, January/February 1984, p 16-17.

${ }^{84}$ Ibid.

${ }^{85}$ The Gallup Report, ed. David w. Moore, Report No. 337, October 1993, p 23.

86 Ibid.

${ }^{87}$ Ibid, p 24.

88 Eric Hammel, The Root. New York: Harcourt Brace Jovanovich, Publishers, 1985, p 425.; Church, p 49.

89 "CNN", p 51.

90 Major General Lewis Mackenzie, Peacekeeper: The Road to Sarajevo. Toronto: Douglas and McIntyre, Publishers, 1993, p 324.

$91_{\text {Smith, p. } 17 .}$

92 William Sutey. "Light Infantry, Augmentation, and the M113A3 Armored Personnel Carrier: A step in the Direction of Versatility." Unpublished monograph, School of Advanced Military Studies, Ft. Leavenworth, Kansas, 19 December 1992, p 34.

93 Michael Mazarr. "Middleweight Forces for Contingency Operations." Military Review. (August 1991):8, pp 38-39.

${ }^{94}$ Smith, p 29.

$95_{\text {Babbit, p } 3 .}$ 


\section{BIBLIOGRAPHY}

\section{Books}

Barnet, Richard. The Rocket's Red Glare: When America Goes to War. New York: Simon and Schuster, 1990.

Bellamy, Chris. The Future of Land Warfare. New York: st. Martin's Press, 1987.

Clausewitz, Karl. On War. ed. Michael Howard and Peter Paret, Princeton: Princeton University Press, 1984 .

Collins, John. America's Small Wars: Lessons for the Future. New York: Brassey's(US), Inc., 1991.

Graber, Doris. Media Power in Politics. United States of America, 3rd ed., 1994.

Grant, Thomas. Little Wars, Big Problems. Irvine, CA: University of California, 1990.

Hammel, Eric. The Root: The Marines in Beirut. New York: Harcourt, Brace, Jovanovich, 1985.

International Peace Academy. Peacekeeper's Handbook. New York: Percamon Press, 1984.

James, Alan. Peacekeeping in International Politics. New York: St. Martin's Press, Inc., 1990.

Linsky, Martin, ed. How the Press Effects Federal Policymaking. New York: W. W. Norton and Company, Inc., 1986.

Mackenzie, Lewis, Peacekeeper: The Road to Sarajevo. Toronto: Douglas and McIntyre Publishers, 1993.

Mazarr, Michael. Light Forces and the Future of U.S. Military Strategy. New York: Brassey's (US), Inc., 1990.

Mowlana, Hamid. Triumph of the Image: the Media's War in the Gulf. Boulder, Co: Westview Press, Inc., 1992 .

Paschall, Rod. LIC 2010. Washington D.C.: Pergamon Press, 1991.

Reisman, Don, ed. World Security Trends and Challenges at Century's End. New York: St Martin's Press, Inc., 1991. 
Roberts, Brad. U.S. Security in an Uncertain Era. Cambridge MA: The MIT Press, 1993.

Sarkesian, Sam and Williams, John. The U.S. Army in a New Security Era. Boulder, Co: Lynee Rienner, 1990 .

Sarkesian, Sam. The New Battlefield. Westport CT: Greenwood Press, Inc., 1986.

Smith, Hedrick, ed. The Media and the Gulf War. Washington, D.C.: Seven Locks Press, 1992.

\section{Articles}

Atkinson, Rick. "The Raid that went Wrong" and "Firefight in Mogadishu." The Washington Post. January 30 and 31,1994 .

Boylan, Peter. "Power Projection, Risk and the Light Force." Military Review. (May 1982): 62-69.

Church, George. "Anatomy of a Disaster." Time. 8 October, 1993.

Doll, William and Metz, Steven. "The Army and Multinational Peace Operations: Problems and Solutions." Strategic Studies Institute special Report. 1993.

Hunt, John. "Hostilies Short of War." Military Review. (March, 1993): 45 .

Jasper, William. "Behind our Defeat in Somalia." The New American. (September 1994): 4-8.

Lief, Louis and Auster, Bruce. "Somalia: What went wrong." U.S. News and World Report. (October 1993): 33-37.

Luttwak, Edward. Historical Analysis and Projection for Army 2000. Chevey Chase, MD: Edward N. Luttwak, 1982. TRADOC contract DABT-58-82-C-0055.

Mazarr, Michael. "Middleweight Forces for Contingency operations." Military Review. (August 1991): 3239.

McAneny, Leslie, ed. The Gallup Report. Report No. 327, (December 1992): 18-19.

McAneny, Leslie, ed. The Gallup Report. Report No. 329, (February 1993): 12-13. 
Milton, Timothy. "Urban Operations: Future War." Military Review. (February 1994): 37-46.

Moore, David, ed. The Gallup Report. Report No. 337, (October 1993): 23-24.

Ord, Robert and Mornstan, Ed. "Light Forces in the Force-Projection Army." Military Review. (January 1994): 22-33.

Schriver, James. "Libyan Raid." The Gallup Report. Report No. 247, (April 1986): 2-12.

220\221, (January $\backslash$ February 1984): 14-17.

- The Gallup Report. Report No. 219, (December 1983): 26 .

Schwarz, Benjamin. Casualties, Public opinion and U.S. Military Intervention: Implications for U.S. Regional Deterence Strategies." Santa Monica, CA: Rand Corporation, 1994.

Stech, Frank. "Winning CNN Wars." Parameters. (Autumn 1994): 37-56.

Thurman, Edward E. "Shaping an Army for Peace, Crisis, and War." Military Review. (April 1992), 27-35.

Tiffany, Allen. "Light Infantry Divisions with More for the Fight." Military Review. (August1991): 40-55.

Wass de Czege, Huba. "Three Kinds of Infantry." Infantry. (July-August 1985): 11-13.

Theses and Monographs

Army Contingency Forces and Marine Corps Expeditionary Forces: Unique or Redundant? William B. Garrett, Major, Ft Leavenworth, Kansas, Combined Arms Library, ADA 274-101, 1993.

The British Experience in Northern Ireland: A Model for Modern Peacemaking Operations? William J.A. Miller, Major, Ft Leavenworth, Kansas, Combined Arms Library, ADA 264-419, 1993.

JRTC to Just Cause: A Case study of Light Infantry Training. R.M. Cronin, LTC, Carlisle Barracks, Army War College, ADA 237-294, 1991. 
Light Infantry, Augmentation, and the M113A3 Armored Personnel Carrier: A step in the Direction of Versatility. William K. Sutey, Major, Ft. Leavenworth, Kansas, Combined Arms Library, ADA $262-564,1993$.

Light Infantry Division Assessment: An Individual Study Project. Zannie Smith, Col., Carlisle Barracks, Army War College, 2 April 1993.

The Light Infantry Division: A Case Study for Greater Robustness in a Downsized Army. F.L. Hagenbeck, Col., Carlisle Barracks, Army War College, ADA 264-491, 1993 .

The Light Infantry Division and Counterguerrilla operations: Organizational Fit or Mismatch? Dennis Dimengo, Major, Ft Leavenworth, Kansas, Combined Arms Library, ADA 225-422, 1990.

Light Infantry Divisions in the New World order. R.R. Babbitt, LTC, Carlisle Barracks, Army War College, $\mathrm{ADA}$ 263-583, 1993.

Night Vision Technology and the Night Attack by Light Infantry. Jim McNulty, Maj, Ft Leavenworth,

Kansas, Combined Arms Library, ADA 262-565, 1993.

Peacemaking: The Brother of Peacekeeping or a Combat operation? Michael D. Barbero, Major, Ft Leavenworth, Kansas, Combined Arms Library, ADA 208-768, 1989 .

Peacemaking: Implications for the U.S. Army. Emmet E. Perry, Jr. Major, Ft Leavenworth, Kansas, Combined Arms Library, ADA 254-157, 1992.

The Role of United States Based Contingency Forces in operations to Restore Order. Harry E. Johnson, Major, Ft Leavenworth, Kansas, Combined Arms Library, ADA 255-131, 1992.

Tactical Requirements for Peacekeeping operations. P.L. Brinkley, Major, Ft. Leavenworth, Kansas, Combined Arms Library, ADA 167-198, 1985.

Tactical Methods for Combatting Insurgencies. Gregory Heritage, Major, Ft Leavenworth, Kansas, Combined Arms Library, ADA 262-607, 1992. 
Government Publications

After Action Review for Operation Restore Hope. Ft Drum, New York: G3 10th Mountain Division, 1994.

The Application of Peace Enforcement: operations at Brigade and Battalion (White Paper). Commandant, U.S. Army Infantry School, 1993.

Counterinsurgency Forces and Soviet Successor States: The Combined Arms Brigade Model. Ft Leavenworth, KS: Foreign Military Studies Office, 1992.

Department of the Army, An Infantryman's Guide to Combat in Built-up Areas. Field Manual 90-10-1, Washington, D.C.: U.S. Government Printing Office, 12 May 1993.

Department of the Army, Military operations in Low Intensity Conflict. Field Manual 100-20, Washington DC: U.S. Government Printing office, 1990 .

Department of the Army, operations. Field Manual 100-5, Washington, D.C.: U.S. Government Printing Office, 14 June 1993, p 1-3.

Department of the Army, Peace Operations (draft). Field Manual 100-23, Washington DC: U.S. Government Printing office, 1994.

National Security Strategy of the United States. Washington, DC: U.S. Government Printing office, July 1994.

Report of the DOD Commission on Beirut International Airport Terrorist Act, October 23, 1983. U.S. Department of Defense, 20 December 1983.

Small Wars Manual. United States Marine Corps, 1940, Reprint 1987.

U.S. Department of Defense, Department of the Army. White Paper 1984: Light Infantry Divisions, John A. Wickham, Jr., Washington, D.C.: U.S. Government Printing Office, 1984.

U.S. Department of State, Todd R. Greentree. The United States and the Politics of Conflict in the Developing World. Washington, D.C.: October, 1990: 13 . 